\title{
In vivo effect of diflubenzuron, administered via mineral salt supplementation, against Haematobia irritans and Rhipicephalus microplus parasitizing cattle
}

\author{
Efeito in vivo do diflubenzuron, administrado via sal mineral, contra Haematobia irritans e
} Rhipicephalus microplus parasitando bovinos

Breno Cayeiro Cruz ${ }^{1}$; Lucas Vinicius Costa Gomes ${ }^{1}$; Willian Giquelin Maciel ${ }^{1}$; Gustavo Felippelli' ${ }^{1}$;

Isabella Barbosa dos Santos ${ }^{1}$; Leonardo Bueno Cruvinel' ${ }^{2}$; Luiz Fellipe Monteiro Couto

Thiago Souza Azeredo Bastos²; Alliny Souza de Assis Cavalcante²; João Eduardo Nicaretta²; Vando Edésio Soares ${ }^{3}$; Alvimar José da Costa ${ }^{1}$; Welber Daniel Zanetti Lopes ${ }^{2,4 *}$

\author{
'Centro de Pesquisas em Sanidade Animal - CPPAR, Faculdade de Ciências Agrárias e Veterinárias, Universidade Estadual Paulista - \\ UNESP, Jaboticabal, SP, Brasil \\ ${ }^{2}$ Centro de Parasitologia Veterinária - CPV, Escola de Veterinária e Zootecnia, Universidade Federal de Goiás - UFG, Goiânia, GO, Brasil \\ ${ }^{3}$ Universidade Brasil, Descalvado, SP, Brasil \\ ${ }^{4}$ Instituto de Patologia Tropical e Saúde Pública - IPTSP, Universidade Federal de Goiás - UFG, Goiânia, GO, Brasil
}

Received July 26, 2018

Accepted September 13, 2018

\begin{abstract}
This study involved two field trials with the aim of evaluating the efficacy of diflubenzuron, via mineral supplementation, against Haematobia irritans parasitizing cattle. Concomitantly with the main trial, a stall test was conducted to ascertain the effects of a different formulation with the same active ingredient against Rhipicephalus microplus, along with the action of diflubenzuron on the reproductive parameters of $R$. microplusfemales that had naturally detached from cattle. Against $H$. irritans, it was observed that the efficacy indexes fordiflubenzuron were low $(\leq 31.3 \%$ or $44.6 \%)$ or null $(0.0 \%)$ throughout the study. The anti-R. microplus efficacy of diflubenzuron, at weekly intervals, ranged from 0.0 to $13.7 \%$ over the entire experimental period. Null efficacy $(0.0 \%)$ was registered for diflubenzuron in relation to the reproductive parameters of $R$. microplusfemales that had naturally detached from cattle. The different diflubenzuron formulations, administered via mineral salt supplementation, did not show satisfactory efficacy indexes against $H$. irritans and $R$. microplus parasitizing cattle, within the experimental design of the present study. In addition, this agent did not present any deleterious effects on the reproductive parameters of $R$. microplus females.
\end{abstract}

Keywords: Benzoylphenyl urea, cattle, chitin synthesis inhibitor, engorged females, reproductive parameters, Rhipicephalus microplus.

\section{Resumo}

O objetivo deste estudo foi avaliar a eficácia do diflubenzuron, administrado via suplementação mineral, contra Haematobia irritans parasitando bovinos, em dois testes à campo. Concomitantemente, foi realizado testes em estábulo para determinar os efeitos de uma formulação diferente, com o mesmo princípio ativo, contra Rhipicephalus microplus, bem como a ação do diflubenzuron nos parâmetros reprodutivos de fêmeas de $R$. microplus recolhidas após desprendimento natural do hospedeiro bovino. Contra $H$. irritans, foi observado que foram baixos $(\leq 31,3 \%$ ou $44,6 \%)$ ou nulos $(0,0 \%)$ os índices de eficácia do diflubenzuron. A eficácia anti- $R$. microplus do diflubenzuron, observada em intervalos semanais, variaram de $0,0 \%$ a $13,7 \%$ durante todo o período experimental. Com relação aos parâmetros reprodutivos das fêmeas de $R$. microplus recolhidas, foi observada eficácia nula $(0,0 \%)$ para o diflubenzuron. Conclui-se que as diferentes formulaçóes administradas via sal mineral no atual estudo, contra $H$. irritans e $R$. microplus parasitando bovinos, não apresentaram eficácia satisfatória. Este agente também não mostrou efeito deletério sobre os parâmetros reprodutivos de fêmeas de $R$. microplus.

Palavras-chave: Benzoylphenyl urea, bovino, inibidor de síntese de quitina, fêmeas ingurgitadas, parâmetros reprodutivos, Rhipicephalus microplus.

\footnotetext{
*Corresponding author: Welber Daniel Zanetti Lopes. Instituto de Patologia Tropical e Saúde Pública - IPTSP, Universidade Federal de Goiás - UFG, Rua 235, s/n, Setor Leste Universitário, CEP 74605-050, Goiânia, GO, Brasil. e-mail:wdzlopes@hotmail.com
} 


\section{Introduction}

Despite the existence of many studies focusing on use of technologies against Rhipicephalus microplus, controlling this ectoparasite continues to be a major challenge in the different regions where it occurs. For many years, this tick species was controlled by using synthetic pyrethroids, organophosphates or even macrocyclic lactones. However, the increasing number of R. microplus populations that are resistant to active agents in these chemical groups (CORRÊA et al., 2015; CRUZ et al., 2015; MACIEL et al., 2016) has led to decreases in their efficacy. In their place, treatments with benzoylphenyl ureas are increasingly being used (CRUZ et al., 2015; GOMES et al., 2015).

Benzoylphenyl ureas belong to a chemical group in which active agents are selective growth regulators of insects. They also act as acaricides, through interference in chitin synthesis, thus making it impossible for larvae and nymphs to complete ecdysis. Consequently, these parasites lose hemolymph and death occurs through dehydration.

These chemicals present high specificity, low toxicity for mammals and long periods of efficacy at low concentrations against R. microplus (RETNAKARAM \& WHIGHT, 1987; GRAF, 1993; BULL et al., 1996). Fluazuron, novaluron and diflubenzuron are the most prominent agents in this group. Regarding diflubenzuron, which is orally administered as a feed additive, studies have indicated that it demonstrates low toxicity towards vertebrates (KEGLEY et al., 2010), low deposition in muscle tissues of fish (WINKALER, 2008) and absence of residues in either meat or milk (TFOUNI et al., 2007). Thus, there is no requirement for withdrawal periods relating to consumption of products from animals that have been treated with this agent.

On the other hand, to the best of our knowledge, relatively few in vivo trials focusing on evaluation of diflubenzuron effects against Haematobia irritans and Rhipicephalus microplus have been published. The relatively scarce information available was the reason for conducting the experiments of the present study.

Thus, the aim of the present study was to analyze the efficacy of diflubenzuron, administered via mineral salt supplementation, against $H$. irritans parasitizing cattle, in two different trials. Concomitantly with the main trial, a stall test was performed, seeking to ascertain the effects of a different formulation of this same active agent against $R$. microplus, along with the action of diflubenzuron on the reproductive parameters of fully engorged females of this tick species after naturally detaching from cattle.

\section{Materials and Methods}

\section{Efficacy against natural infestations of Haematobia irritans}

The field studies were performed on two ranches, located in the municipalities of Formiga, state of Minas Gerais, in the southeastern region of Brazil, and Caçu, state of Goiás, in the central-western region of Brazil. These studies were conducted between December 2013 and April 2014 and between January and May 2015, respectively. On each ranch, 30 non-castrated male calves aged 18 to 20 months were selected from a herd of about 100 animals. The selection criterion was that these calves presented the highest horn fly infestations among the herd. This selection procedure was conducted on study days -2 and -1 , based on $H$. irritans (horn fly) counts over the entire body surface of these animals.

Fly counts were simultaneously conducted by observers on each side of the animal (MACIEL et al., 2015), between 07:00 and 10:00 a.m. The same observer always performed counts on the same side of these animals on all post-treatment dates. Subsequently, they were ranked according to their mean numbers of flies and were placed in two groups of 15 animals each, followed by application of randomly allotted treatments. The cattle were divided into 15 blocks of two animals each, and within each block, the animals were randomly assigned to the treatment groups.

The animals started receiving diflubenzuron (Difly Mosca ${ }^{\circledR}$, Champion Animal Health) on experimental day zero, and administration was performed in accordance with the manufacturer's recommendations. The product was mixed, using a mechanical mixer, with mineral salt at a rate of $1.0 \mathrm{~g}$ per $\mathrm{kg}$ of ready-to-use salt, and was then supplied to the animals. All of these materials came from the same production batch from the manufacturer. This proportion was determined assuming that the consumption of mineralized salt by these animals would be around $60 \mathrm{~g} / \mathrm{head} / \mathrm{day}$. In this case, each animal consumed an average of approximately $120 \mathrm{mg}$ of the diflubenzuron product (Difly Mosca ${ }^{\circledR}$, Champion Animal Health) per day. This formulation was chosen because this is the only form of diflubenzuron commercialized on the Brazilian market against $R$. microplus. The mineral salt mixture containing diflubenzuron was supplied to the animals in covered troughs arranged in the paddocks. For control animals (untreated), the same mineralized salt, without addition of diflubenzuron, was provided. Every seven days, it was observed whether the salt had been ingested. A further $10 \mathrm{~kg}$ of saltwas also addedto the covered troughs by means of an automatic dispensing system, for each group (with or without diflubenzuron), [over the period of the trial? every seven days?].

Starting on experimental day zero, the cattle were kept in different paddocks (A and B), five kilometers apart, in order to prevent horn fly dispersal between the herds. The two paddocks presented the same topographic characteristics (no invading vegetation, nearby forests or places for animals to hide) and the same size and pasture species (Urochloa decumbens).

To evaluate the therapeutic efficacy indexes of each treatment scheme, the presence of $H$. irritans on the entire body surface of each animal was registered on days 3, 7, 14, 21, 28 and every seven days thereafter, until the $160^{\text {th }}$ day after the start of treatment (DAST). Efficacy indexes for the treatments were calculated at each count using the following formula:

$$
\text { Efficacy }=\frac{a-b}{a} \times 100
$$

In this equation, "a" represents the mean number of $H$. irritans specimens on animals in the untreated control group, while "b" represents the mean number of horn flies counted on animals in the treated group. 


\section{Efficacy against artificial $R$. microplus infestations}

\section{Location, animals and pre-treatment infestations}

One experiment was conducted at the Animal Health Research Institute Ltd. (Instituto de Pesquisas em Saúde Animal Ltda., IPESA), which is located in the municipality of Formiga, state of Minas Gerais, southeastern Brazil.

Sixteen seven-month-old crossbred calves, weighing from 168 to $175 \mathrm{~kg}$, which had not received any antiparasite treatment for at least 120 days before the experiment, were selected and identified with numbered ear tags. All the animals were held in individual raised pens (i.e. self-draining pens) that were appropriate for conducting "stall tests", starting on day 27 before treatment (D -27), for an acclimatization period. After this initial stage, each animal was subjected to infestation with approximately 5,000 R.microplus larvae ( $0.25 \mathrm{~g}$ of eggs), aged 14 to 28 days, on experimental days $-24,-21,-19,-17,-14,-12,-10,-7,-5,-3$ and -1 , considering that day 0 was the treatment date (BRASIL, 1997). The animals were restrained in order to apply the infestation. The syringes containing the larvae were applied gently along the dorsal and/or lateral line of the animal, thus allowing the larvae to move and choose a fixation site. The animals were restrained for approximately 60 minutes. This strain of $R$. microplus had been obtained from the same location as that of the present study and had been maintained at IPESA since 2001, using cattle and a BOD incubator. The main compounds used against this strain of $R$. microplus have been macrocyclic lactones, fipronil and fluazuron; this strain has never been previously exposed to diflubenzuron.

\section{Pre-treatment counts of engorged $R$. microplus females detached from cattle, and allocation of animals to treatment groups}

On days $-3,-2$ and -1 , fully engorged $R$. microplus females that naturally detached from each animal were counted. All counts were performed daily, in the mornings (between 08:00 and 09:00 a.m.).

Animals were allocated to treatment groups according to a randomized complete block design. Block formation was based on arithmetic mean counts offemale ticks that became detached from each animal prior to treatment (days -3, -2 and -1), and on individual pen location. In each experiment, the animals were divided into eight blocks of four animals each and, within each block, they were randomly placed in one of the treatment groups, as shown in Table 1 . The blocks were assigned to sets of two nearby

Table 1. Efficacy of diflubenzuron added to mineral salt for controlling Haematobia irritans in crossbred cattle, in the municipality of Caçu, Goiás state, Brazil.

\begin{tabular}{|c|c|c|c|c|c|c|c|c|}
\hline \multirow{2}{*}{$\begin{array}{l}\text { Day of the } \\
\text { study }\end{array}$} & \multirow{2}{*}{$\begin{array}{c}\text { Number of } \\
\text { animals per } \\
\text { group in each } \\
\text { data }\end{array}$} & \multirow{2}{*}{\multicolumn{2}{|c|}{$\begin{array}{c}\text { Untreated } \\
\text { Average infestation/ } \\
\text { Standard deviation } \\
\end{array}$}} & \multirow{2}{*}{\multicolumn{2}{|c|}{$\begin{array}{c}\text { Treated } \\
\text { Average infestation/ } \\
\text { Standard deviation }\end{array}$}} & \multirow{2}{*}{ Efficacy } & \multicolumn{2}{|c|}{ Teste U of Mann-Whitney } \\
\hline & & & & & & & $\mathbf{U}$ & p-value \\
\hline zero & 15 & $88.0 \pm 20.4$ & A & $87.9 \pm 20.4$ & A & - & 111.5 & 0.9835 \\
\hline 3 & 15 & $69.3 \pm 16.9$ & A & $73.9 \pm 28.1$ & A & 0.0 & 106.5 & 0.8195 \\
\hline 7 & 15 & $63.0 \pm 25.0$ & A & $57.8 \pm 20.7$ & A & 8.3 & 105.5 & 0.7875 \\
\hline 14 & 15 & $66.7 \pm 49.5$ & A & $49.3 \pm 28.0$ & A & 26.1 & 100.0 & 0.6187 \\
\hline 21 & 15 & $58.8 \pm 62.1$ & A & $43.4 \pm 15.5$ & A & 26.2 & 98.5 & 0.5755 \\
\hline 28 & 15 & $59.3 \pm 58.1$ & $\mathrm{~A}$ & $40.4 \pm 14.5$ & A & 31.9 & 104.5 & 0.7557 \\
\hline 35 & 15 & $61.1 \pm 54.6$ & A & $53.8 \pm 28.6$ & A & 12.0 & 111.5 & 0.9835 \\
\hline 42 & 15 & $53.3 \pm 23.9$ & A & $49.1 \pm 35.6$ & A & 7.9 & 93.0 & 0.4306 \\
\hline 49 & 15 & $58.8 \pm 39.6$ & A & $40.4 \pm 35.6$ & A & 31.3 & 74.0 & 0.1150 \\
\hline 56 & 15 & $61.9 \pm 30.1$ & A & $66.6 \pm 24.5$ & A & 0.0 & 93.5 & 0.4429 \\
\hline 63 & 15 & $54.7 \pm 26.2$ & A & $56.4 \pm 54.0$ & A & 0.0 & 83.0 & 0.2290 \\
\hline 70 & 15 & $68.3 \pm 56.7$ & A & $48.1 \pm 49.3$ & A & 29.5 & 80.5 & 0.1914 \\
\hline 77 & 15 & $71.3 \pm 60.0$ & A & $66.4 \pm 40.3$ & A & 6.9 & 105.5 & 0.7875 \\
\hline 84 & 15 & $81.7 \pm 56.8$ & A & $60.1 \pm 49.5$ & A & 26.4 & 80.5 & 0.1914 \\
\hline 91 & 15 & $71.5 \pm 60.5$ & $\mathrm{~A}$ & $64.2 \pm 71.5$ & A & 10.3 & 99.5 & 0.6041 \\
\hline 98 & 15 & $96.5 \pm 105.5$ & A & $82.3 \pm 67.9$ & A & 14.7 & 107.5 & 0.8519 \\
\hline 105 & 15 & $79.1 \pm 73.0$ & A & $68.1 \pm 71.9$ & A & 13.9 & 93.0 & 0.4306 \\
\hline 112 & 15 & $104.5 \pm 70.3$ & A & $87.2 \pm 51.1$ & A & 16.6 & 96.5 & 0.5203 \\
\hline 119 & 15 & $102.7 \pm 66.5$ & A & $106.7 \pm 103.3$ & A & 0.0 & 108.0 & 0.8682 \\
\hline 126 & 15 & $60.2 \pm 36.1$ & A & $69.9 \pm 36.2$ & A & 0.0 & 95.0 & 0.4807 \\
\hline 133 & 15 & $42.6 \pm 22.9$ & A & $38.8 \pm 24.5$ & A & 8.9 & 100.0 & 0.6187 \\
\hline 140 & 15 & $37.9 \pm 20.4$ & A & $36.9 \pm 38.3$ & A & 2.6 & 82.0 & 0.2134 \\
\hline 147 & 15 & $24.0 \pm 21.3$ & A & $20.7 \pm 20.8$ & A & 13.6 & 100.5 & 0.6334 \\
\hline 154 & 15 & $19.5 \pm 11.2$ & A & $16.1 \pm 12.1$ & A & 17.1 & 75.5 & 0.1300 \\
\hline 160 & 15 & $19.9 \pm 9.4$ & $\mathrm{~A}$ & $14.0 \pm 8.4$ & A & 29.5 & 70.5 & 0.0852 \\
\hline
\end{tabular}


pens, and the animals within each block were randomly allocated to individual pens within the set. Each animal constituted one experimental unit.

The cattle started receiving diflubenzuron (Difly S3 ${ }^{\circledR}$, Champion Animal Health) on experimental day zero, and administration was performed in accordance with the manufacturer's recommendations. Assuming that salt consumption would be around 60 to $80 \mathrm{~g} / \mathrm{day}$, $17 \mathrm{~g}$ of the tested compoundwere added per kilogram of salt ( $425 \mathrm{~g}$ per $25 \mathrm{~kg}$ bag). For consumption, the product was added to the daily feed, and thus the intake of daily recommended dosages of diflubenzuron by these animals was assured, since all of them consumed all the feed provided. The product used is the only diflubenzuron formulation commercially available for $R$. micropluson the Brazilian market.

\section{Counts of engorged $R$. microplus females detached} from each animal, and post-treatment infestations

Engorged female ticks that had become naturally detached from experimental cattle were counted daily, starting on day 1 , up to the end of each trial $\left(80^{\text {th }}\right.$ DAST). During the post-treatment period, all animals were subjected to infestation with approximately 5,000 viable unfed $R$. microplus larvae twice a week (every Tuesday and Thursday), up to the end of the study, as recommended by Holdsworth et al. (2006).

\section{Assessment of reproductive parameters in pre-selected engorged female ticks}

The following reproductive parameters of engorged female ticks were analyzed: female weight, egg mass weight, hatchability percentage, percentage of reduction in oviposition, percentage of reduction in hatchability, reproductive efficiency and control/efficacy percentage of formulations regarding reproductive parameters.

For this analysis, all engorged female ticks that became detached from animals were collected every morning, from day 1 up to the end of the experiment (day 80). For each group, 10 engorged female ticks were randomly selected each day, weighed, fixed in Petri dishes using scotch tape and moved to a BOD incubator at $27{ }^{\circ} \mathrm{C}$ and approximately $85 \%$ relative humidity, to stimulate oviposition.

After 20 days of laying eggs in the BOD incubator, the engorged female ticks were discarded, and the weights of their egg masses were recorded for each group and each post-treatment day. Subsequently, the egg mass of each group and each post-treatment day was transferred to an adapted $3 \mathrm{ml}$ syringe and was returned to the BOD incubator $\left(27^{\circ} \mathrm{C}\right.$ and approximately $85 \%$ relative humidity), to stimulate larval hatching.

After another 20 days, when larval hatching had ended, the hatchability rate was calculated in accordance with methodology described by Gonzales et al. (1993). The hatchability percentage from each sample group (derived from the daily sample of engorged female ticks) was visually estimated using a stereo microscope with an eyepiece grid, by comparing the proportion of larvae in relation to unhatched eggs for each group and each post-treatment day (DRUMMOND et al., 1973; GONZALES et al., 1993; GEORGE \& DAVEY, 2004; HOLDSWORTH et al., 2006).

\section{Reduction in the number of engorged females counted}

Acaricide efficacy indexes from each formulation were calculated using arithmetic means from counts of engorged female ticks that had become detached from animals in each group. The data thus collected were grouped into seven-day intervals. The formula for this calculation, as recommended by Roulston \& Wharton (1967), is described below:

$$
\text { Efficacy percentage }=\left[1-\frac{T a \times C b}{T b \times C a}\right] \times 100
$$

In this equation, "Ta" represents the average number of engorged female ticks counted on treated animals post-medication; " $\mathbf{T b}$ " is the average number of engorged female ticks counted on treated animals during the three days prior to treatment; "Ca" is the average number of engorged female ticks counted on control animals after the experiment began; and " $\mathbf{C b}$ " is the average number of engorged female ticks counted on control animals during the three days that preceded treatment.

\section{Reproductive parameters of pre-selected engorged female ticks}

To assess the impact of treatments on reduction of oviposition and hatching, the following equations were used, as described by Drummond et al. (1973):

Percentage oviposition reduction $=[$ (average egg mass weight of control group - average egg mass weight of treated group) / average egg mass weight of control group] X 100;

Percentage hatching reduction $=[$ (average hatchability of control group - average hatchability of treated group) / average hatchability of control group] X 100.

To estimate the extent of reproduction and percentage control or efficacy, the following equations, described by Drummond et al. (1973), were applied:

Estimate of reproduction $(\mathrm{ER})=($ egg weight $/$ female weight $)$ $\mathrm{X}$ hatching $\%$ X 20,000

Control or efficacy percentage $=[($ ER of control group $-E R$ of treated group) / ER of control group] X 100.

All experiments were blinded; thus, completely reliable data were obtained. Furthermore, all animals received the envisaged doses of the active agent.

\section{Data analysis}

The data obtained from the counts of $R$. microplus and $H$. irritans did not meet the requisites of normality and homogeneity of variances. The Mann-Whitney U test (at a significance level of 5\%) was used to compare the treatments, within each experimental date, using the npar1way Wilcoxon SAS procedure (SAS Institute, 2008).

\footnotetext{
${ }^{1}$ Constant corresponding to an estimate of the number of larvae contained in $1 \mathrm{~g}$ of eggs.
} 
The numerical observations regarding the reproductive parameters (engorged female weight, egg mass and hatchability) of pre-selected engorged female ticks in both experimental groups met the requisites of normality, homogeneity of variances and residue analysis. The data were analyzed by analysis of variance (ANOVA) using the SAS GLM procedure and the means of the treatments were compared by means of Tukey's test (Tukeys's Stundentized Range - HSD) at a significance level of 5\%.

\section{Results}

No side effects from the treatments were observed among the cattle medicated with different formulations containing diflubenzuron.

\section{Haematobia irritans}

The results regarding average fly counts and efficacy indexes obtained from diflubenzuron treatments in the trial in central-western Brazil are shown in Table 1. It can be seen that the animals kept as untreated controls were constantly challenged by this parasite up to the $126^{\text {th }}$ DAST. In subsequent counts, on the $133^{\text {rd }}, 140^{\text {th }}$, $147^{\text {th }}, 154^{\text {th }}$ and $160^{\text {th }}$ DAST, $H$. irritans infestations in the control group diminished considerably. This interfered with efficacy results on those experimental days. Nonetheless, it could be seen that efficacy indexes for this active agent against horn flies parasitizing cattle were either very low or null throughout the experiment.

This formulation reached a maximum efficacy index of $31.9 \%$ on the $28^{\text {th }}$ DAST. Between the $3^{\text {rd }}$ and $126^{\text {th }}$ DAST, the efficacy values ranged from $0.0 \%$ to around $30 \%$ (Table 1 ). The average horn fly counts obtained among control animals (untreated) did not differ significantly ( $\mathrm{p}>0.05$ ) from the average counts of $H$. irritans on cattle treated with diflubenzuron via mineral salt, on all days of observation post-treatment (Table 1).

In the experiment conducted in the southeastern region of Brazil (municipality of Formiga, state of Minas Gerais), diflubenzuron administered via mineral salt presented no efficacy (0.0\%) against H. irritans parasitizing cattle up to the $77^{\text {th }}$ DAST (Table 2). Between the $84^{\text {th }}$ and $147^{\text {th }}$ DAST, diflubenzuron showed efficacy values ranging from $32.5 \%$ to $44.6 \%$, while immediately afterwards $\left(154^{\text {th }}\right.$ and $160^{\text {th }}$ DAST), the efficacy indexes decreased to $11.4 \%$ and $9.2 \%$, respectively. Statistical analysis on the results from fly counts showed that the average numbers of $H$. irritans on animals that received diflubenzuron via mineral salt were significantly lower $(\mathrm{p} \leq 0.05)$ than the numbers obtained from the untreated control group between the $84^{\text {th }}$ and $140^{\text {th }}$ DAST. On other experimental days, the average numbers of horn flies did not differ significantly $(p>0.05)$ between untreated animals (control) and animals that received diflubenzuron (Table 2 ).

Table 2. Efficacy of diflubenzuron added to mineral salt for controlling Haematobia irritans in crossbred cattle, in the municipality of Formiga, Minas Gerais state, Brazil.

\begin{tabular}{|c|c|c|c|c|c|c|c|c|}
\hline \multirow{2}{*}{$\begin{array}{l}\text { Day of the } \\
\text { study }\end{array}$} & \multirow{2}{*}{$\begin{array}{c}\text { Number of } \\
\text { animals per group } \\
\text { in each data }\end{array}$} & \multirow{2}{*}{\multicolumn{2}{|c|}{$\begin{array}{c}\text { Untreated } \\
\text { Average infestation/ } \\
\text { Standard deviation }^{1}\end{array}$}} & \multirow{2}{*}{\multicolumn{2}{|c|}{$\begin{array}{c}\text { Treated } \\
\text { Average infestation/ } \\
\text { Standard deviation }^{1}\end{array}$}} & \multirow[b]{2}{*}{ Efficacy } & \multicolumn{2}{|c|}{ Teste U of Mann-Whitney } \\
\hline & & & & & & & $\mathbf{U}$ & p-value \\
\hline zero & 15 & $71.4 \pm 18.9$ & A & $71.3 \pm 18.9$ & A & - & 111.5 & 0.9835 \\
\hline 3 & 15 & $69.3 \pm 16.9$ & $\mathrm{~A}$ & $73.9 \pm 28.1$ & A & 0.0 & 106.5 & 0.8195 \\
\hline 7 & 15 & $81.3 \pm 55.1$ & A & $91.1 \pm 54.9$ & A & 0.0 & 94 & 0.4553 \\
\hline 14 & 15 & $81.1 \pm 53.6$ & A & $92.0 \pm 63.8$ & A & 0.0 & 92 & 0.4068 \\
\hline 21 & 15 & $83.5 \pm 49.5$ & A & $90.1 \pm 54.9$ & A & 0.0 & 92 & 0.4068 \\
\hline 28 & 15 & $85.1 \pm 57.6$ & A & $106.1 \pm 48.7$ & A & 0.0 & 79.5 & 0.1776 \\
\hline 35 & 15 & $100.5 \pm 59.7$ & A & $105.3 \pm 61.1$ & A & 0.0 & 107.5 & 0.8519 \\
\hline 42 & 15 & $86.7 \pm 42.9$ & A & $92.6 \pm 69.2$ & A & 0.0 & 111 & 0.9669 \\
\hline 49 & 15 & $105.5 \pm 53.2$ & A & $114.3 \pm 63.6$ & A & 0.0 & 99 & 0.5897 \\
\hline 56 & 15 & $95.9 \pm 43.4$ & $\mathrm{~A}$ & $105.5 \pm 56.2$ & A & 0.0 & 96 & 0.5069 \\
\hline 63 & 15 & $82.6 \pm 55.2$ & A & $95.1 \pm 48.3$ & A & 0.0 & 96.5 & 0.5203 \\
\hline 70 & 15 & $93.3 \pm 40.1$ & A & $96.7 \pm 60.1$ & A & 0.0 & 109 & 0.9010 \\
\hline 77 & 15 & $97.3 \pm 53.9$ & A & $102.5 \pm 49.9$ & A & 0.0 & 102 & 0.6783 \\
\hline 84 & 15 & $128.4 \pm 54.9$ & A & $86.7 \pm 53.4$ & B & 32.5 & 65.5 & 0.0438 \\
\hline 91 & 15 & $90.3 \pm 61.7$ & A & $55.7 \pm 37.9$ & A & 38.3 & 74.5 & 0.1198 \\
\hline 98 & 15 & $103.9 \pm 53.4$ & A & $61.1 \pm 29.6$ & A & 41.2 & 62 & 0.0881 \\
\hline 105 & 15 & $99.9 \pm 70.1$ & A & $55.3 \pm 26.4$ & B & 44.6 & 68.5 & 0.0412 \\
\hline 112 & 15 & $108.5 \pm 53.3$ & A & $65.1 \pm 40.7$ & B & 40.0 & 57.5 & 0.0238 \\
\hline 119 & 15 & $106.0 \pm 37.8$ & A & $65.2 \pm 28.7$ & B & 38.5 & 40.5 & 0.0030 \\
\hline 126 & 15 & $105.1 \pm 50.7$ & A & $60.1 \pm 29.5$ & B & 42.8 & 55 & 0.0181 \\
\hline 133 & 15 & $89.1 \pm 40.2$ & A & $58.3 \pm 26.2$ & $\mathrm{~B}$ & 34.5 & 57.5 & 0.0238 \\
\hline 140 & 15 & $109.8 \pm 34.8$ & A & $69.5 \pm 40.5$ & B & 36.7 & 53.5 & 0.0152 \\
\hline 147 & 15 & $93.7 \pm 46.9$ & A & $60.0 \pm 25.9$ & A & 36.0 & 60.5 & 0.0527 \\
\hline 154 & 15 & $91.5 \pm 38.2$ & A & $81.0 \pm 43.4$ & A & 11.4 & 93 & 0.4306 \\
\hline 160 & 15 & $98.2 \pm 45.0$ & A & $89.1 \pm 59.1$ & A & 9.2 & 89.5 & 0.3507 \\
\hline
\end{tabular}

zero = Mean counts of the days -2 and $-1 .{ }^{1}$ Means values followed by the same letter on the same line for each parameter, do not differ by the test U Mann-Whitney $(\mathrm{p}>0.05)$. 


\section{Rhipicephalus microplus}

The anti- $R$. microplus efficacy of a different formulation containing diflubenzuron, which was calculated based on seven-day tick count intervals, was below 14\% (arithmetic means) during the entire experiment. A maximum efficacy of $13.7 \%$ was reached by this formulation between the $15^{\text {th }}$ and $21^{\text {st }}$ DAST. Between the $22^{\text {nd }}$ and $28^{\text {th }}$ DAST, values of $12.6 \%$ were registered. The efficacy decreased to values lower than $10 \%$ after the $28^{\text {th }}$ DAST (Table 3 ). The average numbers of $R$. microplus on control animals (untreated) did not differ statistically ( $p>0.05$ ) from average numbers of ticks on animals that were subjected to treatment, with diflubenzuron via mineral salt, at any time during the trial (Table 3). Based on concern for animal welfare and good clinical practice, allied to low efficacies demonstrated by diflubenzuron throughout the experiment, all the cattle received specific treatment against $R$. microplus on the $80^{\text {th }}$ DAST and experimental tick counting was discontinued.

Concerning deleterious effects that might have been caused by diflubenzuron to the reproductive parameters of $R$. microplus females, this compound generally presented low or null efficacy. It showed a maximum percentage reduction of oviposition of $3.0 \%$ between the $71^{\text {st }}$ and $77^{\text {th }}$ DAST. On other days, this compound had no effect on this parameter $(0.0 \%)$. Regarding percentage larval hatchability, reduction rates caused by diflubenzuron remained $\leq 7.5 \%$ throughout the trial. These results may have been reflected in the efficiency indexes of this active agent regarding the reproductive parameters of $R$. microplus females, with null efficacy $(0.0 \%)$ observed for diflubenzuron during the entire experimental period (Table 4).

Results from the statistical analysis concerning the reproductive parameters of fully engorged females that had naturally detached from cattle reinforced inferences that had previously been described.
Specifically, regarding tick weights, females obtained from the control group weighed less $(\mathrm{p} \leq 0.05)$ than did the females that became detached from animals that received diflubenzuron on some dates ( $15^{\text {th }}$ to $21^{\text {st }}$ and $29^{\text {th }}$ to $35^{\text {th }}$ DAST). Between the $36^{\text {th }}$ and $42^{\text {nd }}$ and between the $71^{\text {st }}$ and $77^{\text {th }}$ DAST, females selected from cattle that received diflubenzuron were significantly lighter $(\mathrm{p} \leq 0.05)$ than females obtained from untreated animals. The weight of egg masses from females detached from treated cattle was statistically greater $(\mathrm{p} \leq 0.05)$ than the weight of egg masses from $R$. microplus females that were obtained from the control group between the $8^{\text {th }}$ and $35^{\text {th }}$ DAST, and between the $43^{\text {rd }}$ and $56^{\text {th }}$ DAST. Regarding percentagelarval hatching, there was no significant difference $(p>0.05)$ in the values obtained from the two groups, except between the $22^{\text {nd }}$ and $28^{\text {th }}$ DAST, when the percentage of larvae that hatched from the treated (diflubenzuron) group was higher $(p \leq 0.05)$ than the percentage of larvae that hatched from the control group (Table 4).

\section{Discussion}

In vitro, the effects of diflubenzuron on immature stages of $H$. irritans had already been demonstrated by Silva \& Mendes (2002) and Dell'Porto et al. (2012). Silva \& Mendes (2002) showed that third-stage larvae were more susceptible to diflubenzuron than were first and second-stage larvae. Moreover, this active agent achieved 100\% lethality, under laboratory conditions, at concentrations of 300, 100 and 50 ppb. Dell'Porto et al. (2012) found that flies kept as controls presented 86\% emergence (based on egg numbers), while a group cultivated in feces from animals that had been treated with diflubenzuron presented a $1 \%$ rate.

Miller et al. (1986), Cilek \& Knapp (1991) and Tomberlin et al. (2007) studied the efficacy of diflubenzuron directly on hosts.

Table 3. Efficacy of diflubenzuron added to mineral salt for controlling Rhipicephalus microplus in crossbred cattle, in the municipality of Formiga, Minas Gerais state, Brazil.

\begin{tabular}{|c|c|c|c|c|c|c|c|c|}
\hline \multirow{2}{*}{$\begin{array}{l}\text { Day of the } \\
\text { study }\end{array}$} & \multirow{2}{*}{$\begin{array}{l}\text { Number of } \\
\text { animals per group } \\
\text { in each data }\end{array}$} & \multicolumn{4}{|c|}{$\begin{array}{l}\text { Mean value of engorged females detached of } \\
\text { cattle /Experimental groups }\end{array}$} & \multirow{2}{*}{ Efficacy (\%) } & \multicolumn{2}{|c|}{ Teste U of Mann-Whitney } \\
\hline & & $\begin{array}{c}\text { Untreated Average }^{1} \\
\text { infestation/Standard } \\
\text { deviation }\end{array}$ & & $\begin{array}{c}\text { Treated Average } \\
\text { infestation/Standard } \\
\text { deviation }\end{array}$ & & & $\mathbf{U}$ & p-value \\
\hline zero & 8 & $47.1 \pm 16.1$ & A & $51.7 \pm 16.3$ & A & - & 15 & 0.6889 \\
\hline 1 to 7 & 8 & $65.0 \pm 12.5$ & A & $67.0 \pm 26.0$ & A & 6.0 & 16 & 0.8102 \\
\hline 8 to 14 & 8 & $70.3 \pm 13.7$ & A & $72.7 \pm 15.2$ & A & 5.8 & 14 & 0.5752 \\
\hline 15 to 21 & 8 & $79.9 \pm 23.4$ & A & $75.6 \pm 27.7$ & A & 13.7 & 15 & 0.6889 \\
\hline 22 to 28 & 8 & $80.5 \pm 21.2$ & A & $77.2 \pm 34.1$ & A & 12.6 & 13 & 0.4712 \\
\hline 29 to 35 & 8 & $80.6 \pm 7.7$ & A & $80.6 \pm 36.4$ & A & 8.8 & 14 & 0.5752 \\
\hline 36 to 42 & 8 & $82.5 \pm 14.4$ & A & $85.0 \pm 41.0$ & A & 6.1 & 15 & 0.6889 \\
\hline 43 to 49 & 8 & $85.1 \pm 20.4$ & A & $86.1 \pm 27.0$ & A & 7.7 & 18 & 0.9362 \\
\hline 50 to 56 & 8 & $76.6 \pm 22.6$ & A & $86.9 \pm 25.5$ & A & 0.0 & 15 & 0.6889 \\
\hline 57 to 63 & 8 & $84.3 \pm 30.5$ & A & $91.9 \pm 28.5$ & A & 0.6 & 15 & 0.6889 \\
\hline 64 to 70 & 8 & $90.9 \pm 33.1$ & A & $94.0 \pm 28.5$ & A & 5.7 & 17 & 0.9362 \\
\hline 71 to 77 & 8 & $95.0 \pm 27.9$ & A & $93.9 \pm 26.8$ & A & 9.9 & 18 & 0.9362 \\
\hline 78 to 80 & 8 & $94.3 \pm 31.2$ & A & $95.2 \pm 25.5$ & A & 8.0 & 18 & 0.9362 \\
\hline
\end{tabular}

${ }^{1}$ Means values followed by the same letter on the same line for each parameter, do not differ by the test U Mann-Whitney ( $\left.\mathrm{p} \geq 0.05\right)$. 


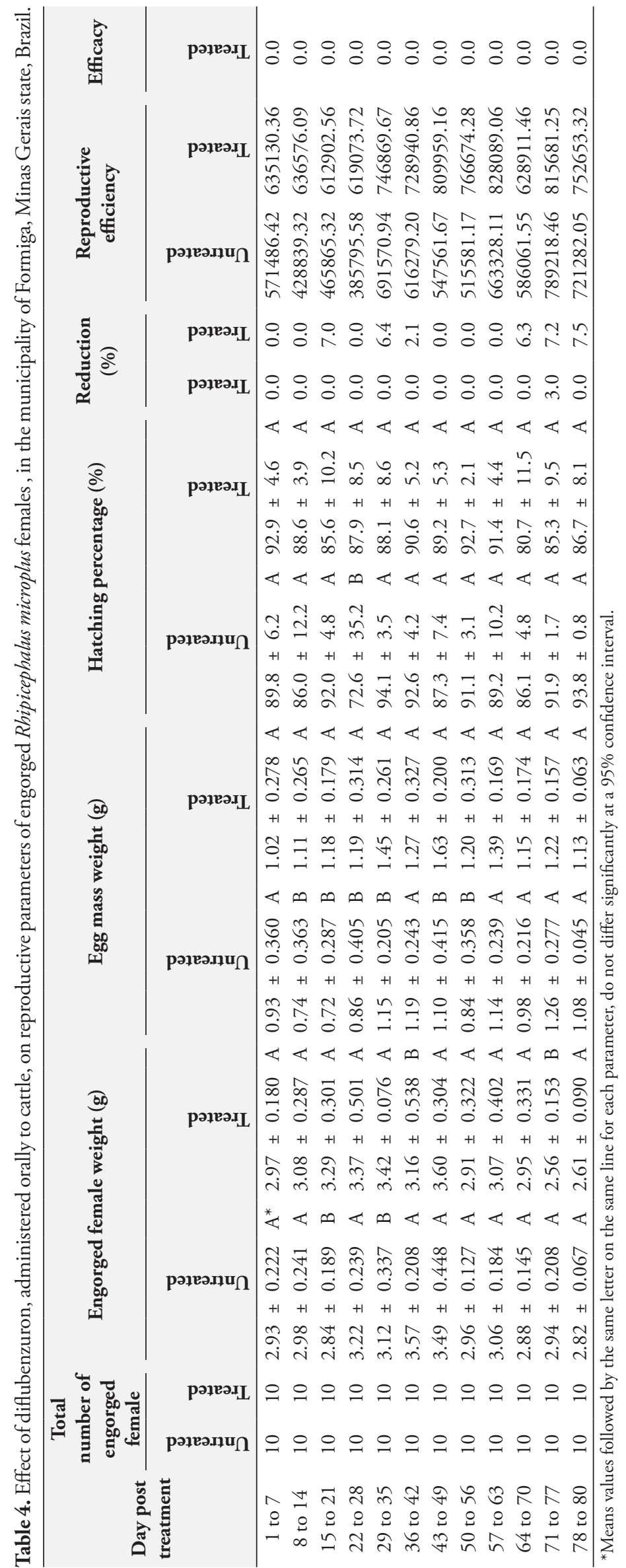


Diflubenzuron was administered as a bolus for cattle in the studies of Miller et al. (1986) and Cilek \& Knapp (1991), in the United States and Canada. These authors collected manure samples and then incubated them at $27^{\circ} \mathrm{C}$ and maintained them for pupation and emergence of adults. Miller et al. (1986) reported that a commercial bolus formulation (10\% diflubenzuron) used in manure samples from treated animalswas able to prevent development of horn fly larvae (Haematobia irritans) (14 weeks of protection), face fly larvae (Musca autumnalis) (17 weeks of inhibition), along with immature stages of stable flies (Stomoxys calcitrans) and house flies (Musca domestica).

A different trial tested diflubenzuron bolus in two cattle herds that were carrying horn flies that were resistant to permethrin and stirophos. Testes treatments reduced resistant populations of adult horn fly population by more than $80 \%$ during the first two and a half months (CILEK \& KNAPP, 1991). Tomberlin et al. (2007) evaluated the flies' capacity to reach the adult stage through recording the percentages of deformed pupae that developed on manure samples from three pastures treated with diflubenzuron (at a dosage of 59 per 0.4 hectares). The capacity of $H$. irritansto reach adult stages was lower in the treated samples than in the control manure samples, on 11 of the 15 sampling dates. Accordingly, a significantly greater percentage of deformed pupae was recorded among the samples from the treated sites $\leq 17$ days post-treatment.

Regarding the field efficacy of diflubenzuron against $R$. microplus, a single trial exists. This was conducted in the municipality of Campo Grande, the capital of the state of Mato Grosso do Sul, in the central-western region of Brazil. Itused beef cattle that were maintained under pasture conditions and were experimentally infested with this ectoparasite (ANDREOTTI et al., 2015). In that study, a reduction in parasite burden of approximately $50 \%$ was observed 15 days after the treatment with diflubenzuron had started, in comparison with cattle that were kept as untreated controls. These authors also observed that diflubenzuron had effects on $R$. microplus only at larval stages. In the present study, using a stall test on artificially infested cattle, diflubenzuron demonstrated minimal efficacy against $R$. microplus, with indexes $\leq 15 \%$ throughout the experiment.

It is important to emphasize that the relatively low efficacy observed in the $R$. microplus studies should not be directly correlated with resistance to the insecticide tested. Although diflubenzuron resistance has been previously reported in the Australian blow fly Lucilia cuprina (KOTZE \& SALES, 2001; LEVOT \& SALES, 2002), resistance of $R$. microplus to this insecticide has not been reported so far. It is also important to highlight that pour-on fluazuron (a compound in the same family as diflubenzuron) has been shown to have elevated therapeutic and residual efficacy ( $\geq 90 \%$ ) on farms where the $R$. microplus strain was the same as the one used for stall tests in the present study (CRUZ et al., 2014; GOMES et al., 2015; MACIEL et al., 2016; LOPES et al., 2017).

The main hypothesis to explain the failure of diflubenzuron in controlling $H$. irritans and $R$. microplus that wasobserved in the present study would be the insecticide administration route. In the studies by Miller et al. (1986) and Cilek \& Knapp (1991), in the United States and Canada, diflubenzuron was administered via a bolus andhad a significant effect against insect larvae. On the other hand, the formulations used in the present study were administered via mineral salt supplementation, in accordance with the manufacturer's recommendations, and there are no known bioavailability studies on this molecule in animals exposed to diflubenzuron via mineral salt.

The route of administration for benzoylphenylureas is a significant factor in relation to the effect of a particular active component (GOMES et al., 2015). Against $R$. microplus, the efficacy indexes for pour-on fluazuron are higher than 90\% (CRUZ et al., 2014; GOMES et al., 2015; MACIEL et al., 2016; LOPES et al., 2017), which contrasts with efficacy rates of less than $50 \%$ for this same molecule administered through the subcutaneous route (GOMES et al., 2015), against the same strain of $R$. microplus. The same may have occurred for diflubenzuron administered via mineral salt, though further studies should be conducted to substantiate this hypothesis.

Another issue that can interfere with the efficacy of a formulation relates to the availability and quantity of the product that can be administered to the animals (when these are supplied to the herd in covered troughs arranged in paddocks). There is also the impact of possible social interactions in this factor, since some cattle present dominance behavior and this may influence the amount of product ingested, in relation to other cattle that are classified as "less dominant". However, it is important to note that, in our study evaluating the efficacy of diflubenzuron against $R$. microplus, the cattle were housed in individual pens, so that the mineral salt containing the active substance was individually provided to the animals.

To the best of our knowledge, there is a lack of studies conducted using diflubenzuron with the aim of evaluating the effects of this molecule on the reproductive parameters of fully engorged $R$. microplus females that naturally detach from cattle. This makes it impossible to discuss or formulate comparative analyses on the data obtained. Nevertheless, based on the results obtained from the present study, diflubenzuron did not lead to any deleterious effects on the reproductive parameters of $R$. microplus, among females that had become detached from cattle during an experiment that was conducted over 80 consecutive days of evaluation.

However, studies on the effects of other insect growth regulators on the cattle tick have shownvarying results. Martins et al. (1995) used different concentrations of fluazuron $(1 \mathrm{mg} / \mathrm{kg}$ and $2 \mathrm{mg} / \mathrm{kg}$ ) and found that there was no oviposition among engorged females on days 7-11 after treatment, or that it occurred at a very low percentage $(<15 \%)$. Mendonça (2010) evaluated a formulation of $3.0 \mathrm{mg} / \mathrm{kg}$ fluazuron $+0.5 \mathrm{mg} / \mathrm{kg}$ abamectin on a different strain of $R$. microplus. They observed that this compound had deleterious effects on the reproductive parameters of fully engorged $R$. microplus females, with $100 \%$ efficacy on several post-treatment days. Cruz et al. (2014) observed oviposition among pre-selected females that had become detached, in groups treated with two formulations $(2.5 \mathrm{mg} / \mathrm{kg}$ fluazuron and $3.0 \mathrm{mg} / \mathrm{kg}$ fluazuron + $0.5 \mathrm{mg} / \mathrm{kg}$ abamectin) over the entire experimental period.

Further in vivo studies with different formulations containing diflubenzuron are needed, in order to understand and elucidate the effects of this active agent against Haematobia irritans and Rhipicephalus microplus parasitizing cattle. The different diflubenzuron formulations administered via mineral salt within the experimental design of the present study, against $H$. irritans and $R$. microplus 
parasitizing cattle, did not show satisfactory efficacy. Nor did this agent show any deleterious effects on the reproductive parameters of $R$. microplus females that had naturally detached from cattle.

\section{References}

Andreotti R, Garcia MV, Matias J, Barros JC, Magalhães GM, Ardson FA, et al. Diflubenzuron effectiveness in cattle tick (Rhipicephalus microplus) control in field conditions. Pharm Anal Acta 2015; 6(6): 373. http:// dx.doi.org/10.4172/2153-2435.1000373.

Brasil. Ministério da Agricultura e Abastecimento. Secretaria de Defesa Agropecuária. Portaria no 48, de 12 de maio de 1997. Diário Oficial da República Federativa do Brasil [online], Brasília, maio 1997 [cited 2018 July 26]. Available from: http://sistemasweb.agricultura.gov.br/sislegis/ action/detalhaAto.do?method=visualizarAtoPortalMapa\&chave=72818869

Bull MS, Swindale S, Overend D, Hess EA. Suppression of Boophilus microplus populations with fluazuron: an acarine growth regulator. Aust Vet J1996; 74(6): 468-470. http://dx.doi.org/10.1111/j.1751-0813.1996. tb07575.x. PMid:9006870.

Cilek JE, Knapp FW. Diflubenzuron as a possible tool for managing insecticide-resistant horn flies (Diptera: Muscidae). J Agric Entomol 1991; 8(1): 7-16.

Corrêa RR, Lopes WDZ, Teixeira WFP, Cruz BC, Gomes LVC, Felippelli G, et al. A comparison of three different methodologies for evaluating Rhipicephalus (Boophilus) microplus susceptibility to topical spray compounds. Vet Parasitol 2015; 207(1-2): 115-124. http://dx.doi. org/10.1016/j.vetpar.2014.11.001. PMid:25468670.

Cruz BC, Lopes WDZ, Maciel WG, Felippelli G, Favero FC, Teixeira WFP, et al. Susceptibility of Rhipicephalus (Boophilus) microplus to ivermectin $(200,500$ and $630 \mu \mathrm{g} / \mathrm{kg})$ in field studies in Brazil. Vet Parasitol 2015; 207(3-4): 309-317. http://dx.doi.org/10.1016/j.vetpar.2014.12.012. PMid:25576441.

Cruz BC, Teixeira WFP, Maciel WG, Felippelli G, Favero FC, Cruz $\mathrm{AC}$, et al. Effects of fluazuron $(2.5 \mathrm{mg} / \mathrm{kg})$ and a combination of fluazuron $(3.0 \mathrm{mg} / \mathrm{kg})+$ abamectin $(0.5 \mathrm{mg} / \mathrm{kg})$ on the reproductive parameters of a field population of Rhipicephalus (Boophilus) microplus on experimentally infested cattle. Res Vet Sci 2014; 97(1): 80-84. http://dx.doi.org/10.1016/j. rvsc.2014.04.012. PMid:24837997.

Dell'Porto A, Hoppe EGL, Gomes AG, Mata RSS, Rocha RMS. Eficácia do diflubenzuron 25\% no controle da Haematobia irritans (Diptera: Muscidae): Desafio in vitro e a campo. Arq Inst Biol 2012; 79(4): 617620. http://dx.doi.org/10.1590/S1808-16572012000400021.

Drummond RO, Ernst SE, Trevino JL, Gladney WJ, Graham OH. Boophilus annulatus and Boophilus microplus: laboratory tests of insecticides. J Econ Entomol 1973; 66(1): 130-133. http://dx.doi.org/10.1093/jee/66.1.130. PMid:4690254.

George JE, Davey RB. Therapeutic and persistent efficacy of a single application of doramectin applied either as a pour-on or injection to cattle infested with Boophipuls microplus (Acari: Ixodidae). J Med Entomol 2004; 41(3): 402-407. http://dx.doi.org/10.1603/0022-2585-41.3.402. PMid:15185941.

Gomes LVC, Lopes WDZ, Cruz BC, Teixeira WFP, Felippelli G, Maciel WG, et al. Acaricidal effects of fluazuron $(2.5 \mathrm{mg} / \mathrm{kg})$ and a combination of fluazuron $(1.6 \mathrm{mg} / \mathrm{kg})+$ ivermectin $(0.63 \mathrm{mg} / \mathrm{kg})$, administered at different routes, against Rhipicephalus (Boophilus) microplus parasitizing cattle. Exp Parasitol 2015; 153: 22-28. http://dx.doi.org/10.1016/j. exppara.2015.02.004. PMid:25728230.

Gonzales JC, Muniz RA, Farias A, Gonçalves LCB, Rew RS. Therapeutic and persistent efficacy of doramectin against Boophilus microplus in cattle. Vet Parasitol 1993; 49(1): 107-119. http://dx.doi.org/10.1016/03044017(93)90229-G. PMid:8236733.

Graf JF. The role of insect growth regulators in arthropod control. Parasitol Today 1993; 9(12): 471-474. http://dx.doi.org/10.1016/01694758(93)90106-P. PMid:15463697.

Holdsworth PA, Kemp D, Green P, Peter RJ, De Bruin C, Jonsson NN, et al. World Association for the Advancement of Veterinary Parasitology (W.A.A.V.P.) guidelines for evaluating the efficacy of acaricides against ticks (Ixodidae) on ruminants. Vet Parasitol 2006; 136(1): 29-43. http:// dx.doi.org/10.1016/j.vetpar.2005.11.011. PMid:16377090.

Kegley SE, Hill BR, Ormes S, Choi AH. Pesticide database. San Francisco: Pesticide Action Network; 2010.

Kotze AC, Sales N. Inheritance of Diflubenzuron resistance and monooxygenase activities in a laboratory-selected strain of Lucilia cuprina (Diptera: Calliphoridae). J Econ Entomol 2001; 94(5): 1243-1248. http:// dx.doi.org/10.1603/0022-0493-94.5.1243. PMid:11681690.

Levot GW, Sales N. New high level resistance to diflubenzuron detected in the Australian sheep blowfly, Lucilia cuprina (Wiedemann) (Diptera: Calliphoridae). Gen Appl Entomol 2002; 31: 43-45.

Lopes WDZ, Chiummo RM, Vettorato LF, Rodrigues DC, Sonada RB. The effectiveness of a fixed-dose combination pour-on formulation of $1.25 \%$ fipronil and $2.5 \%$ fluazuron against economically important ectoparasites and associated pharmacokinetics in cattle. Parasitol Int 2017; 66(5): 627-634. http://dx.doi.org/10.1016/j.parint.2017.05.005. PMid:28527785.

Maciel WG, Lopes WDZ, Cruz BC, Teixeira WFP, Felippelli G, Sakamoto CAM, et al. Effects of Haematobia irritans infestation on weight gain of Nelore calves assessed with different antiparasitic treatment schemes. Prev Vet Med 2015; 118(1): 182-186. http://dx.doi.org/10.1016/j. prevetmed.2014.11.006. PMid:25465474.

Maciel WG, Lopes WDZ, Gomes LVC, Cruz BC, Felippelli G, Santos IB, et al. Susceptibility of Rhipicephalus (Boophilus) microplus to fluazuron $(2.5 \mathrm{mg} / \mathrm{kg})$ and a combination of novaluron $(2.0 \mathrm{mg} / \mathrm{kg})+$ eprinomectin $(0.36 \mathrm{mg} / \mathrm{kg})$ in field studies in Brazil. Prev Vet Med 2016; 135: 74-86. http://dx.doi.org/10.1016/j.prevetmed.2016.10.019. PMid:27931932.

Martins JR, Corrêa BL, Ceresér VH. Ação carrapaticida do Fluazuron, formulação "pour-on", sobre o carrapato bovino Boophilus microplus. Pesq Agropec Gaúch 1995; 1(2): 257-261.

Mendonça RP. Segurança clínica, atividade endectocida e farmacocinética de residuos de uma nova alternativa terapêutica (fluazuron + abamectina) em bovinos [tese]. Jaboticabal: Universidade Estadual Paulista; 2010.

Miller JA, Knapp FW, Miller RW, Pitts CW, Weintraub J. Diflubenzuron bolus for control of fly larvae. J Agric Entomol 1986; 3(1): 48-55.

Retnakaram A, Whight JE. Control of insect pests with benzoylphenyl ureas. In: Wright JE, Retnakaran A. Chitin and benzoylphenyl ureas. Boston: W. Junk; 1987. p. 205-282.

Roulston WJ, Wharton RH. Acaricide tests on the bjarra strain of organophosphorus resistant cattle ticks Boophilus microplus from southern Queensland. Aust Vet J 1967; 43(4): 129-134. http://dx.doi. org/10.1111/j.1751-0813.1967.tb08916.x. PMid:6067998.

SAS Institute. SAS/STAT 9.2 user's guide. Cary: SAS Institute; 2008. 
Silva JJ, Mendes J. Effect of diflubenzuron on immature stages of Haematobia irritans (L.) (Diptera: Muscidae) in Uberlândia, State os Minas Gerais, Brazil. Mem Inst Oswaldo Cruz 2002; 97(5): 679-682. http://dx.doi.org/10.1590/S0074-02762002000500017. PMid:12219135.

Tfouni SAV, Furlani RPZ, Araújo JD, Souza RM. Avaliação da presença de resíduos em leite de vacas tratadas com diflubenzurom. Rev Inst Adolfo Lutz 2007; 66(3): 230-233.
Tomberlin JK, Lohmeyer KH, Kattes D. Treatment of pasture with diflubenzuron suppresses horn fly, Haematobia irritans (Diptera: Muscidae) development. J Agric Urban Entomol 2007; 24(2): 95-101. http://dx.doi. org/10.3954/1523-5475-24.2.95.

Winkaler EU. Aspectos ecotóxicológicos dos inseticidas diflubenzuron e teflubenzuron para o pacu (Piaractus mesopotamicus) [tese]. Jaboticabal: Universidade Estadual Paulista; 2008. 